\title{
Insights into North Atlantic deep water formation during the peak interglacial interval of Marine Isotope Stage 9 (MIS 9)
}

\author{
Zohra Mokeddem $^{1}$ (1) Jerry F. McManus ${ }^{1}$
}

Received: 23 June 2016 / Accepted: 16 December 2016 / Published online: 5 January 2017

(C) The Author(s) 2017. This article is published with open access at Springerlink.com

\begin{abstract}
Foraminifera abundance and stable isotope records from ODP Site $984\left(61.25^{\circ} \mathrm{N}, 24.04^{\circ} \mathrm{W}, 1648 \mathrm{~m}\right)$ in the North Atlantic are used to reconstruct surface circulation variations and the relative strength of the North Atlantic Deep Water (NADW) formation over the period spanning the peak warmth of Marine Interglacial Stage (MIS) 9e ( 324-336 ka). This interval includes the preceding deglaciation, Termination 4 (T4), and the subsequent glacial inception of MIS 9d. The records indicate a greatly reduced contribution of NADW during T4, as observed in more recent deglaciations. In contrast with the most recent deglaciation, the lack of a significant NADW signal extended from T4 well into the peak interglacial MIS 9e and persisted nearly until the transition to the subsequent glacial stage MIS 9d. Although NADW formation resumed during MIS 9e, only depths greater than $2000 \mathrm{~m}$ appear to have been ventilated. The poorly ventilated intermediate depth of Site $984(<2000 \mathrm{~m})$ may have resulted on one hand from a general reduction of deep water ventilation by NADW during the study interval or, on the other hand, from different pathways of the spread of newly formed NADW that bypassed the study location. The intermediate depths may have also been invaded by southern-sourced waters as the formation of intermediate depth NADW weakened. The absence of any significant NADW signal at the water depth of Site 984 during the climatic optimum contrasts sharply with subsequent interglacial peaks (MIS $5 \mathrm{e}$ and the Holocene). Despite the perturbed intermediate depth circulation, oceanic heat transport northeastward was
\end{abstract}

Zohra Mokeddem

zohramokeddem@gmail.com

1 Lamont-Doherty Earth Observatory, Columbia University, Palisades, New York, USA not interrupted and may have contributed to the relatively mild interglacial conditions of MIS 9e.

Keywords MIS 9e $\cdot$ Reduced NADW $\cdot$ Poor ventilation . Intermediate depth

\section{Introduction}

The Middle and Late Pleistocene have been characterized by repeated glaciations lasting tens of thousands of years, interspersed with much shorter relatively warm interglacial intervals, including the Holocene, which began approximately 11,000 years ago following the last ice age (Hays et al. 1976; Imbrie et al. 1984). Although no perfect analogue exists for this most recent interval, previous peak interglacial intervals cover a range of similar climate forcing and response, and thus provide insights into the natural progression and variability of Holocene climate (Tzedakis et al. 2009; Yin and Berger 2015; Working Group of PAGES 2016).

The Holocene is also the most recent of four particularly prominent peak interglacial intervals within the last half million years (Imbrie et al. 1992; Lisiecki and Raymo 2005). Studies of various portions of this interval have indicated that climatic conditions, ocean heat transport and deep water formation in the subpolar North Atlantic have oscillated on different time scales during previous glacial and interglacial intervals, with global consequences (Raymo et al. 1990; Alley 1999). The climatic and oceanographic variations within three of the four prominent warm intervals in the North Atlantic, including the current interglacial (Holocene), the last interglacial peak (MIS 5e), and the warm interval $400 \mathrm{ka}$ (MIS 11) have all drawn substantial interest (i.e., Denton and Karlén 1973; McManus 
et al. 1994, 2002, 2003; O'Brien et al. 1995; Bond et al. 1997; Hall et al. 1998; Chapman and Shackleton 1999; Cortijo et al. 1999; Bond 2001; Oppo et al. 1997, 2001, 2006; Shackleton et al. 2002; Mayewski et al. 2004; Hodell et al. 2009; Voelker and de Abreu 2011; Mokeddem et al. 2014, and references therein), yet comparatively little attention has been dedicated to MIS 9 and its peak warming, MIS 9e (Tzedakis et al. 2004; Roucoux et al. 2006; Desprat et al. 2009; Voelker and de Abreu 2011).

The fact that MIS 9e occurred under somewhat different orbital configurations, greenhouse gas concentrations and global ice volume, based on high-resolution benthic $\delta^{18} \mathrm{O}$ records and major ice-rafting events, from the other three recent peak interglacial intervals (Imbrie et al. 1992; McManus et al. 1999; Petit et al. 1999; Stirling et al. 2001; Waelbroeck et al. 2002; Tzedakis et al. 2009; Berger and Loutre 2010; Lang and Wolff 2010; Working Group of PAGES 2016), make it useful for comparison with the Holocene. Indeed, while somewhat similar insolation parameters characterized both interglacial intervals (Ruddiman 2007; Herold et al. 2012; Yin and Berger 2015), atmospheric $\mathrm{CO}_{2}$ concentrations within MIS 9e were briefly the highest observed in Antarctic ice core records for the last $800 \mathrm{ka}$ (Luthi et al. 2008), adding to its interest as a target for investigation.

MIS 9 has been subdivided into five substages (Tzedakis et al. 1997) with the climatic peak optimum (MIS 9e), having an estimated duration of $11.6 \mathrm{ka}$ (Stirling et al. 2001; Tzedakis et al. 2012; Working Group of PAGES 2016), characterized by one of the most strongly contrasting records of sea surface temperature variation at high latitudes in the North Atlantic. While a general agreement of sustained relatively cool sea surface temperatures is suggested in records of the Nordic Seas (Koç et al. 2001; Helmke and Bauch 2003), a wider range of climatic assessments emerges from the northeastern subpolar Atlantic Ocean (McManus et al. 1999; Kandiano et al. 2004; Kostygov et al. 2010; Rodrigues et al. 2011). Although these studies disagreed about the exact level of warm sea surface temperatures within MIS 9e, they generally agreed that it may have been somewhat reduced compared with the Holocene, as the establishment of interglacial warming was abbreviated at an early stage (Venz et al. 1999; Flower et al. 2000; Voelker and de Abreu 2011). This evidence of relatively mild interglacial conditions in the high latitude North Atlantic contrasts in turn with global sea level records indicating diminished continental ice (Shackleton 1987; Stirling et al. 2001; Lisiecki and Raymo 2005) and with southern hemisphere records, which suggests that MIS 9 was nearly the most prominent interglacial interval (Petit et al. 1999; Hodell et al. 2000; King and Howard 2000).

Given the fact that MIS 9e occurred under climatic boundary conditions (Desprat et al. 2009; Rodrigues et al.
2011) that differed from those of the subsequent peak interglacial intervals, it offers an opportunity to assess different climatic influences, including the role of ocean dynamics and its associated heat transport. In this study, we therefore examine the variations in surface and deep hydrographic properties throughout the interval containing MIS 9e at a key location in the subpolar North Atlantic and assess the changes in deep ocean circulation. We then consider their implications for heat transport to the north and deep water formation during MIS 9e compared with the climatic conditions that occurred within the subsequent intervals of peak interglacial warmth, MIS 5e, and the Holocene.

\section{Site location and oceanic setting}

Ocean drilling program (ODP) Site 984 is located on the Bjorn drift in the Iceland Basin $\left(61.25^{\circ} \mathrm{N}, 24.04^{\circ} \mathrm{W}\right.$, $1648 \mathrm{~m}$ ), in the northeast subpolar Atlantic Ocean (Fig. 1). The study area is highly sensitive to water mass mixing and stratification (Read 2000) at the oceanic front that separates the warm subtropical water mass and cold northern sourced water mass (Ruddiman and McIntyre 1973; Ruddiman 1977; Oppo et al. 2006; Mokeddem et al. 2014). It is bathed at depth by the Iceland Sea Overflow Waters (ISOW) that contribute to the modern NADW (Oppo et al. 2006, 2015; Thornalley et al. 2013), and also sits within the core of the Glacial North Atlantic Intermediate Water (Oppo and Lehman 1993; Raymo et al. 2004; Curry and Oppo 2005; Praetorius et al. 2008). Sediments at the site are a mixture of primarily fine-grained detrital silts, microfossil $\mathrm{CaCO}_{3}$, and variable but lesser amounts of biogenic opal and ice-rafted sand (Raymo et al. 1997; Praetorius et al. 2008; Mokeddem et al. 2014). Accumulation rates vary, reaching maximum values over $30 \mathrm{~cm} / \mathrm{ka}$, and averaging $\sim 14 \mathrm{~cm} / \mathrm{ka}$ for the study interval of MIS 9, allowing centennial-scale resolution of oceanographic and climatic conditions at this location. The quality and quantity of accumulating sediments at this oceanographically sensitive location have yielded valuable insights in a number of previous studies (Curry et al. 1999; Schrag et al. 2002; Raymo et al. 2004; DePaolo et al. 2006; Came et al. 2007; Praetorius et al. 2008; Mollenhauer et al. 2011; Thornalley et al. 2013; Mokeddem et al. 2014; Mokeddem and McManus 2016).

\subsection{Modern deep Atlantic water mass distribution}

Ocean heat transport from the tropical region to higher latitudes in the North Atlantic includes a contribution from the Atlantic meridional overturning circulation (AMOC) in which the southward spread of deep flows is compensated by warm, shallow currents flowing north and 
Fig. 1 Map of the North Atlantic Ocean illustrating the geographic locations of ODP Site 984 and the sites used for comparison marked with dark circles. Modern mean annual (2013) distribution of Sea Surface Temperature in the north Atlantic region is based on World Ocean Atlas (http:// data.nodc.noaa.gov/las). Arrows refer to modern deep ocean circulation (McCartney and Talley 1984; Schmitz and McCartney 1993): ISOW Iceland Scotland Overflow Water, DSOW Denmark Strait Overflow Water, LSW Labrador Sea Water, $N A D W$ North Atlantic Deep Water, MOW Mediterranean Overflow Water, GIN Greenland-Iceland-Norwegian

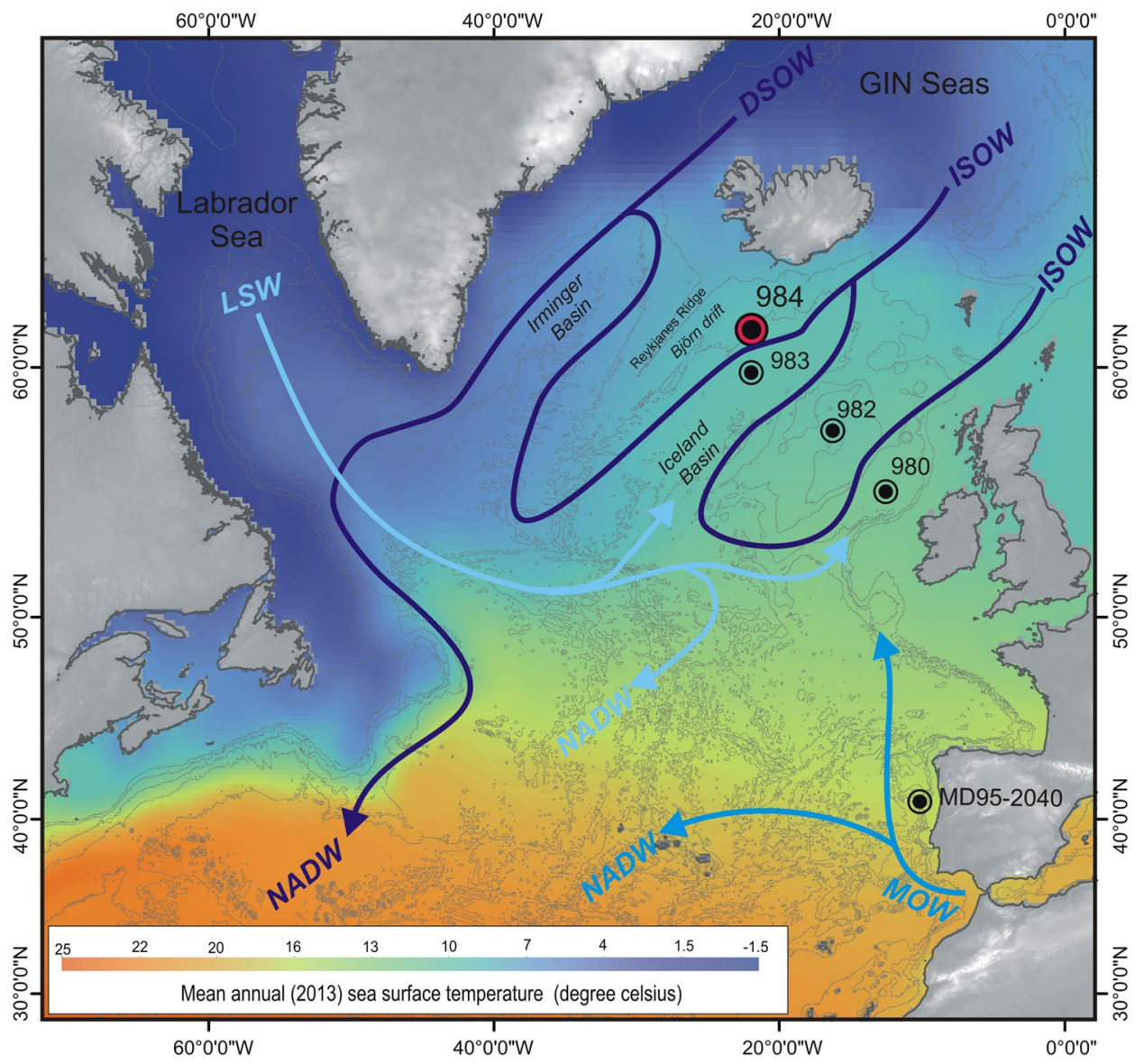

northeastward. These saline near-surface waters are then converted through sinking processes into the North Atlantic Deep Water (NADW) within the subpolar Atlantic and Nordic Seas (McCartney and Talley 1984). The newly formed NADW flows southward within the deep western basin of the Atlantic Ocean. The formation of NADW is crucial in order to maintain the global thermohaline circulation overturning and deep ocean ventilation processes in the subpolar Atlantic (Broecker et al. 1992). In the modern hydrographic setting, NADW fills the depth range between 1000 and $4000 \mathrm{~m}$. Depending on the origin of its formation, NADW is subdivided into two water masses, with depths above 2000 m occupied by the Upper NADW (UNADW) and beneath $2000 \mathrm{~m}$ by the Lower NADW (LNADW). The latter has its origin in the Greenland-Iceland-Norwegian (GIN) Seas overflowing the Denmark Strait (DSOW) (Worthington and Wright 1970; Dickson and Brown 1994). The UNADW is less dense than the LNADW. It is largely formed in the Labrador Sea by open ocean convection, and is therefore often called as the Labrador Sea Water (LSW). These water masses spread from their respective source regions and combine to form NADW, which then mixes at intermediate depths with the relatively warm, highly saline Mediterranean Outflow Water (MOW), and at greater depth with the fresher, cold Southern Ocean Water (SOW) (McCartney 1992). The water mass characteristics of NADW in the subpolar Atlantic records may be affected by the variable contributions of SOW at depth (Boyle and Keigwin 1987; Oppo and Fairbanks 1987), although the characteristic of NADW signature is recognizable in its higher $\delta^{13} \mathrm{C}$ of $\Sigma \mathrm{CO}_{2}$ values compared with SOW (Kroopnick 1985).

\subsection{Glacial/interglacial deep Atlantic water distribution}

Changes in the density of waters in the northern North Atlantic, such as such as by freshening of surface waters inflowing to the GIN Seas, greatly influence the formation of NADW (Dickson and Brown 1994). It has long been recognized that during stadials and glacial maxima marine ice-sheets and icy fresh water masses may have been associated with diminished heat transport to the high latitude North Atlantic (Broecker and Denton 1989; Raymo et al. 1990; Imbrie et al. 1992; Henry et al. 2016). In addition, each major ice sheet collapse was associated with the release of, abundant icebergs that drifted southward and melted primarily in the subpolar Atlantic (Ruddiman 1977; Heinrich 1988; Broecker et al. 1992; McManus et al. 
1998, 1999; Hemming 2004; Naafs et al. 2013). Melted ice contributes fresh water to the sea-surface that would stratify the upper water column and reduce the formation of NADW (Broecker and Denton 1989; Flower et al. 2000). Under these conditions, the upper warm surface branch of the thermohaline circulation is highly perturbed and the production of NADW is diminished. Although the formation of true NADW ceases (Oppo and Fairbanks 1987; Curry et al. 1988), it is substituted during glacial intervals by the formation of the Glacial North Atlantic Intermediate Water (GNAIW) (Boyle and Keigwin 1987; Oppo and Fairbanks 1987; Oppo and Lehman 1993; Curry and Oppo 2005; Marchitto and Broecker 2006). During peak interglacial intervals, the formation of NADW recovers and ocean heat transport is restored (Broecker and Denton 1989; Raymo et al. 1990, 2004; Imbrie et al. 1992). Although they are likely formed under different climatic conditions, NADW and GNAIW share a few important recognizable characteristics such as nutrient-depletion and high $\delta^{13} \mathrm{C}$ values that differentiate them from the SOW masses, which are enriched with nutrients and characterized by lower $\delta^{13} \mathrm{C}$ (Oppo and Fairbanks 1987; Marchitto and Broecker 2006).

\section{Methods}

A suite of paleoceanographic proxies was examined using Site 984 sediments, including stable oxygen and carbon isotopes $\left(\delta^{18} \mathrm{O}\right.$ and $\left.\delta^{13} \mathrm{C}\right)$ of planktic and benthic foraminifera shells, the relative abundance of planktic foraminifera species and the abundance of coarse lithic fragments interpreted as ice-rafted debris (IRD). The percentages of IRD in the sediments were assessed as an indicator of the dynamics of neighboring Northern Atlantic ice-sheets (Heinrich 1988; McManus et al. 1998; Hemming 2004; Naafs et al. 2013). The IRD fraction contains primarily quartz and feldspar, with some amphibole and hornblende, rock fragments, and volcanic glass.

The samples used in this study were sampled at $1 \mathrm{~cm}$ interval. All samples were wet sieved through a $63 \mu \mathrm{m}$ mesh sieve and then dry sieved on a $150 \mu \mathrm{m}$ screen. Foraminiferal and IRD counts were performed on the $>150 \mu \mathrm{m}$ fraction under a stereomicroscope at x50 magnification. A minimum of at least 400 foraminifera specimens or ice rafted grains were counted. In addition to the epifaunal benthic foraminifera Cibicidoides spp, three planktic foraminifera were counted and picked for stable isotopes analyses $\left(\delta^{18} \mathrm{O}\right.$ and $\left.\delta^{13} \mathrm{C}\right)$. While $\delta^{18} \mathrm{O}$ reflects the local variation of the properties of seawater masses flowing through the Iceland Basin, $\delta{ }^{13} \mathrm{C}$ shows the variation of deep ocean water mass properties at a regional level. The isotope measurements were performed on a gas-source mass spectrometer at Rutgers University's
Wright Stable Isotope Laboratory and determined relative to the Vienna Peedee belemnite (VPDB) standard.

The planktic foraminifera species used in this study for abundance distribution and stable isotopes are $N$. Neogloboquadrina (N.) pachyderma sinistral (s.), Neogloboquadrina (N.) incompta and Turborotalia (T.) quinqueloba. These planktic foraminifera species have been successfully used to trace oceanic fronts in the Nordic Seas and the North Atlantic (i.e., Ruddiman 1977; Johannessen et al. 1994; Fronval et al. 1998; Mokeddem et al. 2014). The abundance of the planktic foraminifera $N$. pachyderma (s.) indicates cold polar waters (Bé 1960; Bé and Tolderlund 1971; Kohfeld et al. 1996) while T. quinqueloba has been proposed as a best indicator of the Arctic front and water mass (Bé 1960; Bé and Tolderlund 1971; Johannessen et al. 1994), defining the limit between Arctic water mass to the north and warmer Atlantic water mass located to the south (Mokeddem et al. 2014; Mokeddem and McManus 2016). The species $N$. incompta belongs to the subpolar province (Kučera 2007). It has a broad temperature tolerance and occurs in moderate abundance from the subtropics to the southern limit of the Arctic province (Bé and Tolderlund 1971; Imbrie and Kipp 1971; Johannessen et al. 1994). The abundance of $N$. incompta is considered here in combination with other warm water mass species (Kučera 2007) such as Globigerina bulloides, Globorotalina inflata and Orbulina universa. These other species were counted as one assemblage. With much higher abundance, $N$. incompta was counted separately.

The epibenthic foraminifera, used in this study for $\delta^{18} \mathrm{O}$ and $\delta^{13} \mathrm{C}$, belonging to the genus Cibicidoides, are indicated as Cibicidoides spp. The carbon isotope ratio $\left(\delta^{13} \mathrm{C}\right)$ in Cibicidoides spp is a well-established indicator of bottom water chemistry (Curry et al. 1988; Duplessy et al. 1988; Curry and Oppo 2005). We use it along with the planktic indicators to examine the deep circulation associated with the overlying oceanographic changes. The foraminifera $\delta^{18} \mathrm{O}$ analyzed here is considered to be approximately in equilibrium with seawater $\delta^{18} \mathrm{O}$ and temperature (Kohfeld et al. 1996; Ostermann et al. 2001; Jonkers et al. 2010). The epibenthic C. wuellerstorfi and other species of Cibicidoides exhibit no significant differences in $\delta^{13} \mathrm{C}$ (Curry et al. 1988) and secrete calcite in close isotopic equilibrium with seawater $\delta^{18} \mathrm{O}$ (Bemis et al. 1998; LynchStieglitz et al. 1999). The polar waters indicator N. pachyderma (s.) is the only species that dwells in both polar and subpolar environments with high seasonal temperature and salinity changes, as well as, glacial/interglacial contrasted conditions. The species precipitates at isotopic equilibrium with surface waters colder than $8^{\circ} \mathrm{C}$, and in warmer surface waters it changes its habitat depth or its growth season at an ambient temperature (Wu and Hillaire-Marcel 1994). Thus, 
only north of the polar front that isotopic offsets are generally found (Duplessy et al. 1991; Kohfeld et al. 1996).

The chronostratigraphy on Site 984 records was built by direct tuning of benthic $\delta^{18} \mathrm{O}$ to the deuterium $(\delta \mathrm{D})$ composition of ice in the EPICA Dome Concordia (EDC) Antarctica ice core (Jouzel et al. 2007) following the method proposed and applied elsewhere (Shackleton et al. 2000; Heusser et al. 2006). An alignment of Site 984 data (benthic $\delta^{18} \mathrm{O}$ and $\delta^{13} \mathrm{C}$ ) with major paleoclimatic data was also useful to reconstruct the age model (Fig. 2).

\section{Water column hydrography inferred from foraminifera depth habitat}

The records obtained from Site 984 captured the oceanographic changes that include the abrupt deglaciation known as termination 4 (Broecker and van Donk 1970; Raymo et al. 1997) at the end of the glacial stage MIS 10 and the peak interglacial interval MIS 9e followed by the glacial inception through the interval of MIS 9d (Fig. 3).

The peak increase of IRD deposits $(\sim 338-336 \mathrm{ka})$ indicates the $\mathrm{T} 4$ transition that defines deglaciation processes related with the collapse of northern North Atlantic icesheets. At the close of the deglaciation, reduced fresh and cold water supplies from glaciers and icebergs to the south of Iceland are mainly conveyed through the East Greenland current (Rudels et al. 2002) before they spread south. Warm waters, advected to the region by the Irminger Current, meet and interact with remnant cold waters creating sharp boundary of highly variable values of salinity and temperature, known as the oceanic frontal zone (Fedorov 1986; Ginzburg and Kostianoy 2002). The position of the North Atlantic subpolar frontal zone is variable in space and time, depending on the changing gradients of temperature, salinity and density between colliding cold and warm water masses. Stable oxygen and carbon isotope ratios $\left(\delta^{18} \mathrm{O}\right.$ and $\delta^{13} \mathrm{C}$ ) mark the changing properties of ocean layers at the transition. Less marked in benthic than in planktic, $\delta^{18} \mathrm{O}$ values decrease sharply within $\mathrm{T} 4$. The dynamics of icesheets and sea-ice may have been similar to those recorded in subpolar Atlantic within the subsequent interglacial intervals (McManus et al. 1994; Oppo and Lehman 1995; Bond et al. 1997; Bond 2001; Oppo et al. 2006; Irval1 et al. 2012; Mokeddem et al. 2014). The abundance of the planktic species $N$. pachyderma (s.) and the high abundance of IRD were highly useful to identify the transition prior to MIS 9e, which is also marked by the near absence of subpolar and subtropical foraminifera taxa (Fig. 3).

\subsection{Early MIS 9e}

In early MIS 9e (335-336 ka), ice-rafting decreased dramatically within the first decades of the peak warming. Minimal percentages of IRD (2-4\% per total sediment content) are recorded throughout the peak warm interval, indicating the absence of tidewater glaciers until the ensuing growth of regional ice-sheets that occurred during MIS
Fig. 2 Major paleoclimatic data used to reconstruct or to align Site 984 age model. $a$ LR04 Benthic oxygen isotope stack (Lisiecki and Raymo 2005). $b \delta$ D composition of ice in the EDC ice core, Antarctica (Jouzel et al. 2007). $c, d$ Benthic foraminifera oxygen and carbon isotope records of Site 984 (McManus et al. 1999) complemented with the new data obtained in this study (symbols). e Summer insolation values expressed in watts per square meter $\left(\mathrm{w} \mathrm{m}^{-2}\right)$ for latitude $60^{\circ} \mathrm{N}$ (Berger and Loutre 1991). $f$ Percentage of Ice rafted debris (IRD) of ODP Site 980 (McManus et al. 1999). The gray thick lines delimit the boundaries of MIS 9e, MIS 5e and the Holocene. The thick orange bars represent age model tie points

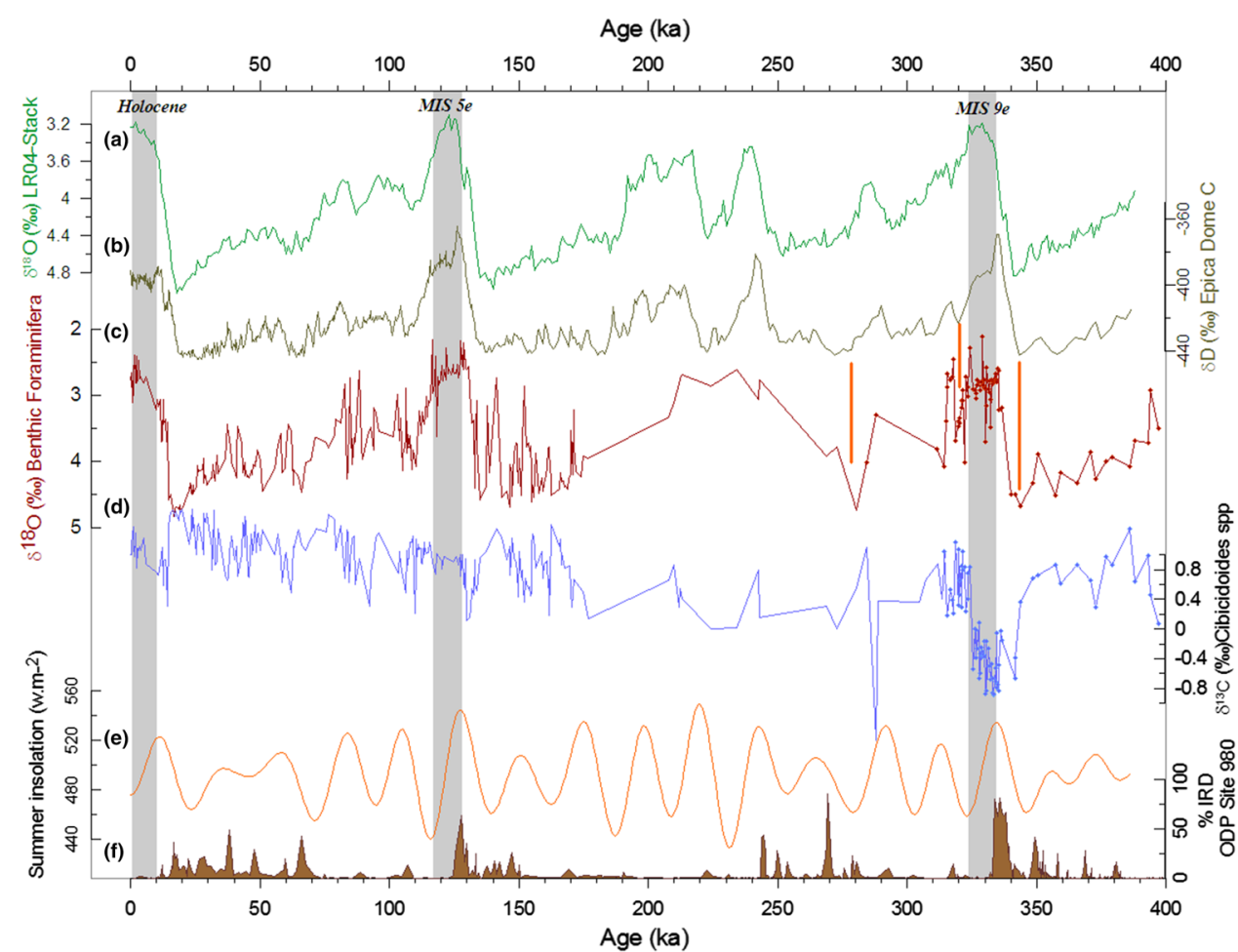




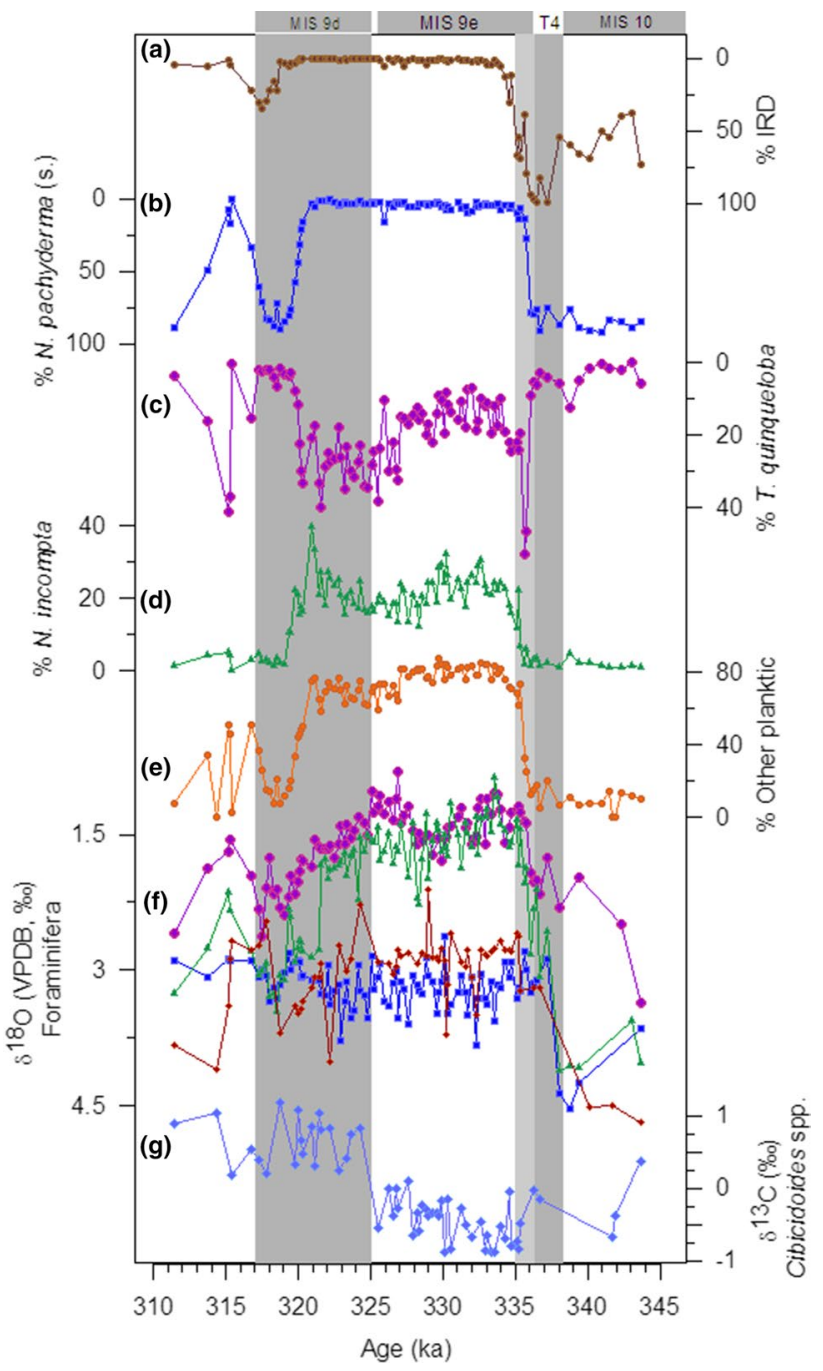

Fig. 3 Data obtained in this study on Site 984 plotted against age in kilo-annum (ka). $a$ until $e$ Percent content of specific planktic foraminifera and ice rafted debris (IRD) plotted against age (ka). $a-c$ The y axes are inverted. $e$ Other Planktic Forams refers to the subpolar and subtropical planktic foraminifera (Globigerina bulloides, Globorotalina inflata and Orbulina universa, etc.) counted as one assemblage indicator of warm water masses. $f \delta^{18} \mathrm{O}$ composition of specific planktic and benthic foraminifera: T. quinqueloba (circle symbols); $N$. incompta (triangle symbols); N. pachyderma (s.) (square symbols); Cibicidoides spp (diamond symbols). $g \delta^{13} \mathrm{C}$ composition of the epifaunal benthic genus Cibicidoides

9d, at $319 \mathrm{ka}$. Throughout MIS 9e, the absence of the cold water taxa indicator $N$. pachyderma (s.) and greatly reduced ice-melting process in the region suggest the retreat of polar waters entirely from the northeast subpolar Atlantic region and increased sea surface temperature (Kandiano and Bauch 2003). The prevalence of warm water mass conveyed through the Irminger current induced an increase of the subpolar species $N$. incompta and other subpolar and subtropical planktic taxa. It also suggests a strong and persistent warm water inflow to the subpolar northeast
Atlantic. During the transition from T4 to the early stage of MIS 9e ( 335.5-336.5 ka), foraminifera abundance display a brief substitution of the polar species $N$. pachyderma (s.) with the Arctic water mass indicator T. quinqueloba (Fig. 3). This may reflect the retreat of the Arctic front and water mass northward from the open North Atlantic across the location of Site 984 and north of Iceland. Cold water masses (polar and Arctic) were pushed northward by a persistent and stronger warm subtropical water mass entering the Iceland Basin through the Irminger Current. At the time T. quinqueloba reached its peak abundance demonstrating the junction with the closest position of the Arctic front ( $\sim 336 \mathrm{ka})$, the abundance of $N$. incompta and the other subpolar and subtropical taxa remained relatively reduced. Following the subsequent decrease in T. quinqueloba abundance, warm waters became dominant in the vicinity of Site 984, as reflected in the increase of $N$. incompta and the other subpolar and subtropical taxa. We conclude from the consecutive series of systematic changes in the abundance of foraminifera indicators at the onset of the early warming stage that a well-subdivided subpolar Atlantic into three domains (Polar, Arctic and subpolar) with three different properties inherited from the severe glacial stadial MIS 10 (McManus et al. 1999) were preserved south of Iceland for several centuries between late T4 and early MIS 9e, before the Arctic and polar domains retreated northward.

\subsection{The MIS 9e interglacial peak}

Both planktic and benthic $\delta^{18} \mathrm{O}$ continued to decrease through T4 until reaching minimum values in early MIS $9 \mathrm{e}$. They generally remained low for more than $11 \mathrm{ka}$ $(\sim 324-335 \mathrm{ka})$. The $\delta^{18} \mathrm{O}$ trends within this peak interglacial interval are distinctly subdivided into two groups, with relatively subtle changes in the isotopic gradient in the species within each group. Lower $\delta^{18} \mathrm{O}$ values are recorded in T. quinqueloba and $N$. incompta, and higher values are recorded in $N$. pachyderma (s.) and Cibicidoides spp. Because any global changes were shared and minimal, the observed values may be regarded as an indication of the difference in the hydrographic properties associated with each species' vertical or seasonal habitat. The trends observed here can therefore be used as indications of water column stratification (Mulitza et al. 1997; Hillaire-Marcel et al. 2001; Jonkers et al. 2010), above and below the thermocline, or an indication of the difference in seasonal flux timing (Chapman 2010; Jonkers et al. 2013). The absence of a significant $\delta^{18} \mathrm{O}$ gradient between $N$. incompta and $T$. quinqueloba may be interpreted as evidence of a mixed upper water column from early spring to early summer (Ganssen and Kroon 2000). The species $N$. incompta abundance peaks in spring and summer in warm stratified 
surface waters overlapping T. quinqueloba abundance in spring bloom (Sautter and Thunell 1989; Ostermann et al. 1998; Weinelt et al. 2001; Simstich et al. 2003; Chapman 2010). The relatively similar values in both $T$. quinqueloba and $N$. incompta may reflect similar vertical hydrographic properties distribution across the water layers where both species dwell. They may also reflect temperature variation as a stronger water parameter in the mixed layer in the absence of salinity variation due to subdued freshwater input.The cold species indicator $N$. pachyderma (s.) varies in depth habitat where the conditions of low temperature are favorable (Weinelt et al. 2001), within a depth range of approximately 150 to $200 \mathrm{~m}$ (Bauch et al. 1997; Simstich et al. 2003). While $T$. quinqueloba and $N$. incompta $\delta^{18} \mathrm{O}$-values show mainly density variations in the upper mixed layer, $N$. pachyderma (s.) recorded density variations within the pycnocline underneath the mixed layer. Throughout MIS $9 \mathrm{e}$, its $\delta^{18} \mathrm{O}$ remains more than $1 \%$ higher than the shallower-dwelling planktics, possibly suggesting a very strong shallow stratification, although more likely due to a seasonal preference for colder months by this polar form (Wu and Hillaire-Marcel 1994). Individuals of $N$. pachyderma (s.) record a mean value very similar to that recorded in the epibenthic Cibicidoides genus. From early to late MIS 9e, the overall $\delta^{18} \mathrm{O}$ trend recorded in $N$. pachyderma (s.) may indicate limited variations of the water density below the mixed layer similar to that of the deepest layer at Site 984 . The high $\delta^{18} \mathrm{O}$ of N. pachyderma (s.) was established within the melting process of $\mathrm{T} 4$, as $N$. pachyderma (s.) tends to migrate to deeper water layers during meltwater events (Weinelt et al. 2001). When warm surface advanced at the end of $\mathrm{T} 4$, the difference of water properties between the mixed layer and deeper layers may have created a sharp vertical front isolating the intermediate and deep water layers from the upper mixed water layer. The $\delta^{18} \mathrm{O}$ of $N$. pachyderma (s.) remained constant throughout MIS 9e until mid MIS 9d ( 322-319 ka) when a decreasing trend occurred suggesting an ascendance of the species to near surface layer, as freezing conditions prevailed and the mixed layer thinned. Potential changes in the seasonal flux may be considered of minor influence given the magnitude of surface temperature changes associated with the glacial-interglacial transition and the glacial inception into MIS 9d (Chapman et al. 2000; Pflaumann et al. 2003). Along with the N. pachyderma (s.) $\delta^{18} \mathrm{O}$ record, the benthic $\delta^{18} \mathrm{O}$-values are nearly constant, other than a few short departures, from early MIS 9e onward until mid MIS 9d. This plateau is similar to that described for MIS 5e (Shackleton et al. 2002) is likely associated with relatively stable global sea level and deep hydrography at Site 984.

\subsection{Glacial inception and MIS 9d}

Because the abundance of the $N$. pachyderma (s.) remained negligible, the Arctic front and water mass apparently never transited the vicinity of Site 984 within the entire climatic optimum of MIS 9e. Nevertheless, we infer that the Arctic front's southern boundary was never far north from Site 984, as T. quinqueloba occurred in significant abundance. In late MIS 9e ( 327 ka), an increase in T. quinqueloba average abundance (17-30\%) and the increasing trend in its $\delta^{18} \mathrm{O}$ values indicate a likely closer fresh and cold water inflow which modified near surface water density, suggesting the advance of a colder water mass, consistent with the Arctic front. These conditions were maintained until the onset of the glacial substage MIS 9d several thousand years later.

From late MIS 9e to mid-MIS 9d ( 327-319 ka), $T$. quinqueloba abundance remained relatively constant, indicating a close and stable position of the Arctic front and water mass in the vicinity of Site 984 . Within this same interval, despite the persistent inflow of cold water and possibly sea-ice in near-surface water layers, $N$. incompta increased and briefly reached its maximum abundance at $321 \mathrm{ka}$. We infer that the southward progress of the Arctic front closer to Site 984 contributed to the decrease of SST in the mixed layer, which may have compelled $N$. incompta to migrate to a deeper warmer layer, in the thermocline, seeking its preferred range of temperatures (Fairbanks et al. 1982; Field 2004). Within this late-interglacial interval, a small increase in N. pachyderma (s.) was noted at the nearby Site 983 (Barker et al. 2015). The juxtaposition of this nearby increase with the highest T. quinqueloba abundance at Site 984 supports the likelihood that a sharp frontal gradient existed south of Iceland at that time. The increasing trend in $N$. incompta $\delta^{18} \mathrm{O}$ at Site 984 that had started in late MIS $9 \mathrm{e}$ became steadier in very early MIS $9 \mathrm{~d}$, as the species reached its maximum abundance before a sharp reversal. We also note a decrease of $N$. pachyderma (s.) $\delta^{18} \mathrm{O}$ record from $322 \mathrm{ka}$ until $319 \mathrm{ka}$, that could be an indication of the migration of the species to a colder upper layer, coincident with the suggested migration of $N$. incompta to a slightly deeper yet warmer water layer. The other subpolar and subtropical planktic foraminifera began to decrease at $320.5 \mathrm{ka}$. The number of $N$. pachyderma (s.) increased considerably around $320.5 \mathrm{ka}$, eventually approaching $100 \%$ of the total fauna, thus reflecting the onset of neighboring ice-sheets' glacial dynamics followed by the progression of the polar front towards Site 984 . The N. pachyderma (s.) $\delta^{18} \mathrm{O}$ trend decreased toward lighter values while all other $\delta^{18} \mathrm{O}$ trends kept on increasing toward heavier values. As proposed above, the N. pachyderma (s.) $\delta^{18} \mathrm{O}$ trend supports the suggestion of 
an upward migration of $N$. pachyderma (s.) to a shallower water depth where its preferred cold conditions occurred near the surface.

After the main collapse of the ice-sheets discernible by a major IRD peak ( 317-318 ka), the polar front began to retreat northward, as attested by the decrease of $N$. pachyderma (s.) abundances from 90 to $10 \%$ and concomitant increase of subpolar and subtropical planktic species that reflects the reduction of cold water inflow south of the Iceland Basin. Just at the occurrence of the IRD peak, a strong water column mixing occurred, visible in all $\delta^{18} \mathrm{O}$ data. The synchronous shift of $N$. incompta and T. quinqueloba to heavier $\delta^{18} \mathrm{O}$ values, and $N$. pachyderma (s.) and Cibicidoides spp to lighter $\delta^{18} \mathrm{O}$ values intercross and almost reach the same value at $2.75 \%$, indicating strong vertical water mixing. The latter may have been brief and may have ended with the transition to the substage interglacial MIS $9 c$.

\section{Deep water variations}

Benthic $\delta^{13} \mathrm{C}$ records from Site 984 trace the evolution of the chemistry of waters bathing the location at $1648 \mathrm{~m}$ depth. These are most likely to reflect nutrient content of the waters, in inverse proportion (Curry et al. 1988; Duplessy et al. 1988). The records obtained within the interval that extends from late MIS 10 through T4 are not included in the full discussion due to the scarcity of Cibicidoides spp $\delta^{13} \mathrm{C}$ data (Fig. 3).

During MIS 9e, benthic $\delta^{13} \mathrm{C}$ at Site 984 reaches minimum values as low as $-0.9 \%$ with a mean value of about $-0.5 \%$ early on, and an overall mean of $-0.35 \%$. Although variable, the values generally increase throughout MIS 9e. This general trend is followed by a remarkable sharp increase of $\delta^{13} \mathrm{C}$ at the transition to MIS 9d. Within this early glacial substage, the records remained relatively high, with a mean value of $\sim 0.55 \%$ ofor several thousand years until a drop to a mean value of $0.25 \%$ ofollowing the onset of IRD deposition at about $317 \mathrm{ka}$. Although this drop of mean $\delta^{13} \mathrm{C}$ values was associated with the start of ice-dynamics in the region, the values did not return to those evident within MIS 9e. Those low values suggest a persistent reduction of NADW throughout much of the interval when oceanic environment was ice-free and polar water mass-free as indicated by the very low $N$. pachyderma (s.) and IRD abundance.

\subsection{Regional deep water mass variations}

To better constrain the changes of the hydrographic properties at a regional level along the northeastern Atlantic deep water masses, we compared the data obtained at Site
984 with the few available records from the North Atlantic region with approximately similar millennial data resolution, concentrating on those from intermediate water depths or slightly deeper.

Benthic oxygen isotope records from ODP Sites 982, 983, 980 and MD95-2040 located respectively at 1145, 1983, 2170 and $2465 \mathrm{~m}$ water depth, compared with Site $984(1648 \mathrm{~m})$, trace the evolution of deep water temperature and isotopic composition related to ice volume and salinity in bottom waters at each site within the interval encompassing T4 and the optimum warming MIS 9e (Fig. 4). The benthic $\delta^{13} \mathrm{C}$ data reflect the isotopic composition in dissolved inorganic carbon, related to variations in deep water ventilation at different bathymetries, along a northeast Atlantic Ocean transect, with an emphasis on the NADW formation signal.

For this comparison, the age model of ODP Site 982 (Venz et al. 1999) was modified from its original scale by alignment of the peak in IRD recorded at T4 with that recorded at Site 984. All other records are plotted using their respective unrevised chronologies.

Benthic $\delta^{13} \mathrm{C}$ displays large variations at each site, indicating fluctuations in the characteristics of water masses at different depths and latitudes (Fig. 4). Although a few factors may affect the $\delta^{13} \mathrm{C}$ signal (i.e., Grossman 1987; Curry et al. 1988), the variability at each site and gradients between sites may largely be interpreted as reflecting the influence of different hydrologic properties of the water masses involved (Oppo and Lehman 1993; Curry et al. 1998, 1999; McManus et al. 1999; Venz et al. 1999; Raymo et al. 2006). One prominent factor that influences variations in the local benthic $\delta^{13} \mathrm{C}$ is the mixing of water masses that have different isotopic compositions (Curry et al. 1988, Oppo and Horowitz 2000).

Our interpretations are made in the context of modern and previously inferred deep water masses, as well as the observed influences on benthic $\delta^{13} \mathrm{C}$. Benthic foraminifera in the shallowest sediments at Site 984 display oxygen and carbon ratios that reflect the influence of the NADW. The modern hydrographic properties of NADW (Dickson and Brown 1994) may be subdivided into UNADW and LNADW, and have been proposed to be similar to that of previous interglacial periods (Duplessy et al. 1984; Oppo and Fairbanks 1990; Raymo et al. 1990, 2004; Venz et al. 1999). In contrast, abundant benthic $\delta^{13} \mathrm{C}$ evidence has emerged indicating that the hydrographic settings of deep and intermediate-depth ocean layers were quite different during glacial stages (i.e., Duplessy et al. 1988, Oppo and Lehman 1993; Curry et al. 1999; Raymo et al. 2004; Curry and Oppo 2005; Lynch-Stieglitz et al. 2007; Gebbie 2014, Oppo et al. 2015).

According to these studies, glacial conditions were characterized by diminished NADW formation and an increase 


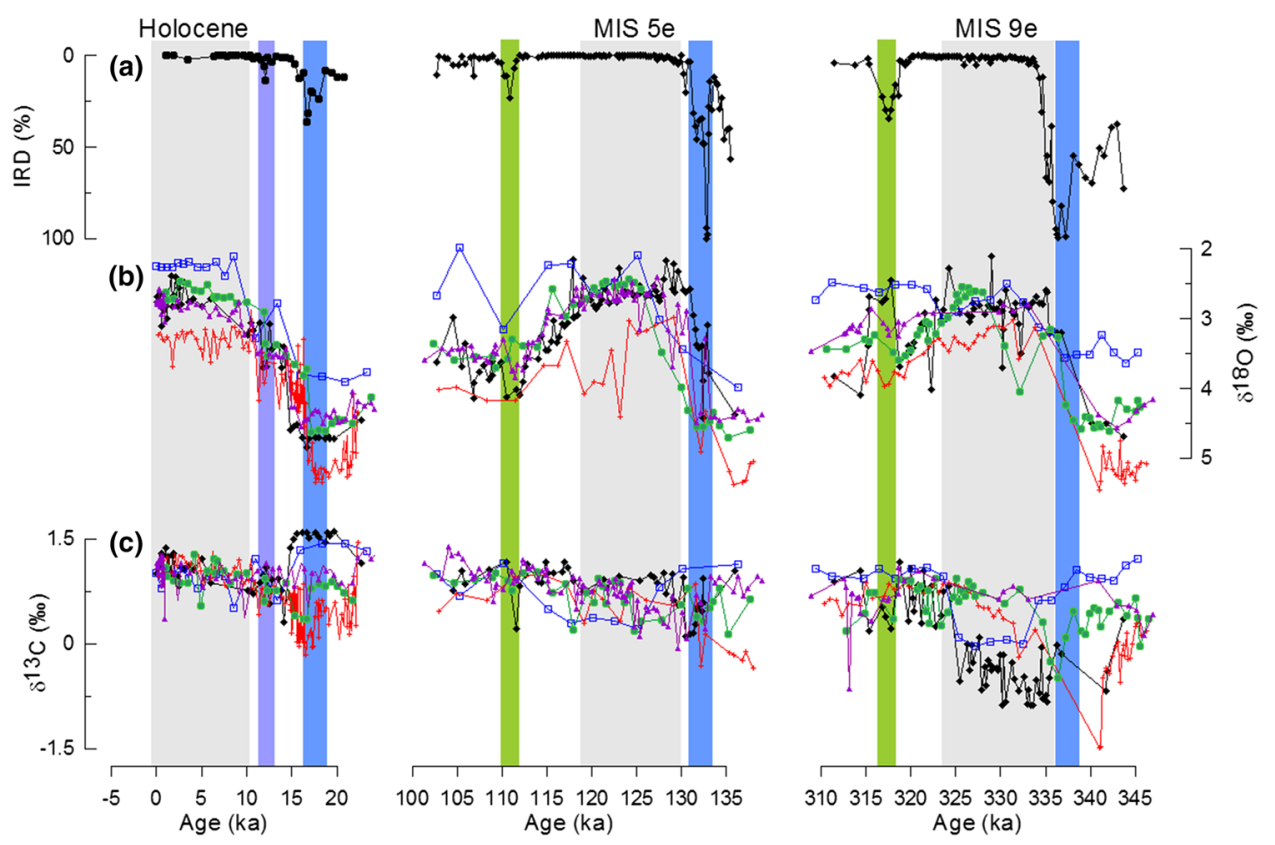

Fig. 4 Comparison of Site 984 data with records from North East Atlantic for the three interglacial intervals: MIS 9e, MIS 5e and the Holocene. Data from each site are plotted on their own timescale. $a$ IRD percentages from Site 984 for MIS 9e and MIS 5e intervals and from Site 980 for the Holocene (Praetorius et al. 2008). $b$ and $c \delta^{18} \mathrm{O}$ and $\delta^{13} \mathrm{C}$ composition of the epibenthic Cibicidoides wuellerstorfi from Site 980 (circle symbols) (McManus et al. 1999; Oppo

in mid-depth North Atlantic ventilation, that may have contributed to reduced heat transport. Although the low-resolution of $\delta^{13} \mathrm{C}$ data at Site 984 across T4 does not allow a better discrimination of NADW variations, the records suggest a general trend from glacial into interglacial suggesting a switch from somewhat higher ventilation within the glacial stage into a less well ventilated interval during T4. Benthic $\delta^{13} \mathrm{C}$ values at Site MD95-2040 were low, although perhaps indicating a greater contribution of MOW at that location on the Iberian margin (Voelker and de Abreu 2011). In contrast, benthic $\delta^{13} \mathrm{C}$ values at Sites 980 and 982 were high during late MIS 10, suggesting the presence of an active glacial intermediate water production that would also have influenced Site 984 (Oppo and Lehman 1993; Venz et al. 1999). The poor ventilation in deep and intermediate water within $\mathrm{T} 4$ and subsequent resumption of NADW at the transition to MIS 9e is best displayed in $\delta^{13} \mathrm{C}$ records at Site 980 (McManus et al. 1999).

During MIS 9e, Site 982 had higher $\delta^{13} \mathrm{C}$ values suggesting that it may have been located closer to the core of NADW (Venz et al. 1999) compared with site 984, yet Sites 980 and 983 recorded even higher $\delta^{13} \mathrm{C}$ values of $\sim 1 \%$, indicating a well-ventilated water mass (McManus et al. 1999; Barker et al. 2015). The MD95-2040 site, located far away from the source production of NADW and et al. 2006), species from the genus Cibicidoides from Site 983 (triangle symbols) (Raymo et al. 2004; Barker et al. 2015), species from the genus Cibicidoides from Site 982 (square symbols) (Venz et al. 1999), the epibenthic species Cibicidoides wuellerstorfi from MD952040 (cross symbols) (Voelker and de Abreu 2011), and species from the genus Cibicidoides from Site 984 (McManus et al. 1999) and this study (diamond symbols)

at the deepest location compared with site ODP 984, displays higher values. All records show clearly that the shallowest and northernmost sites display the lowest $\delta^{13} \mathrm{C}$ values. Although all sites considered in this study are located south of the arctic/polar fronts within the subpolar region, they are nevertheless under different relative influences of NADW and SOW.

The benthic $\delta^{18} \mathrm{O}$ data suggest the presence of similar hydrographic conditions at all the sites, implying the absence of any strong stratification of intermediate and deep water layers. Yet the contrasting $\delta^{13} \mathrm{C}$ suggests different ventilation of intermediate $(<2000 \mathrm{~m})$ and deep (>2000 m) water layers. Site $982(1145 \mathrm{~m})$, located on the Rockall Plateau, is ideally situated to monitor the history of intermediate-depth water circulation under the influence of the UNADW. As Site 984 is also located at a water depth in the intermediate range $(<2000 \mathrm{~m})$ it is likely that the two locations may have been under the influence of the same deep water mass.

Site 980 was bathed by a well-ventilated LNADW with a stronger signal of northern sourced water mass (McManus et al. 1999) while the shallower branch (UNADW) was poorly ventilated probably resulting from mixing with a water mass of a lower $\delta^{13} \mathrm{C}$ ratio, most likely of southern origin (Curry et al. 1988; Curry and Oppo 2005) or 
increased residence time at depth (Oppo et al. 2015). Dense SOW may spread isopycnally into the northern Hemisphere from the deep Southern Ocean with $\delta^{13} \mathrm{C}$ value of $<-0.2 \%$ (Curry and Oppo 2005). There is also evidences that SOW may penetrate into the deep North Atlantic as far as $60^{\circ} \mathrm{N}$ effecting water shallower than $2000 \mathrm{~m}$ (Curry and Oppo 2005; Rickaby and Elderfield 2005; Praetorius et al. 2008; Xie et al. 2014). It has generally been observed that low benthic $\delta^{13} \mathrm{C}$ resulting from mixing with southern sourced water mass occurred only during glacial and deglacial intervals (Boyle and Keigwin 1982, Oppo and Fairbanks 1987; Curry et al. 1988; Raymo et al. 1990; McManus et al. 1999; Flower et al. 2000; Oppo et al. 2015). Low $\delta^{13} \mathrm{C}$ values have also been related to delaying UNADW formation until well after full interglacial conditions were established (Venz et al. 1999; Flower et al. 2000) or, in this case, the entire duration of the interglacial peak, which can be tied up to conditions of source areas for either MOW or Labrador Sea Water (LSW) (Venz et al. 1999). Site MD95-2040 bathed in the deepest water mass and located on the path of MOW produces $\delta^{13} \mathrm{C}$ records that suggest fairly ventilated LNADW (Voelker et al. 2010). The Labrador Sea, a potential source of intermediate water, may have been under the effect of minima in salinity and therefore density. This could be the result of enhanced freshwater input from the Arctic into the Labrador Sea as well as recirculated cold, fresh LSW confined to the subpolar gyre (McCartney and Talley 1984) and entrained by NADW during its spread southwestwards at depth into the Labrador Sea. When the LSW formation was not enabled, enhanced freshwater from the Arctic probably occurred (Hillaire-Marcel et al. 2001; Yang et al. 2016).

\subsection{Deep water variation compared to subsequent interglacial peaks}

Subsequent to MIS 9e, three interglacial intervals occurred globally, including the prominent warmings of the last interglacial, MIS 5e, and the Holocene (Fig. 4). For consistency propose, the records previously obtained on Site 984 for MIS 5e and the Holocene, and obtained in this study are compared with data from the three same interglacial intervals obtained on the sites discussed in the previous section.

The three intervals show similarities regarding the terminations of the glacial stages and also the transition into the following glacial stages in the case of MIS5e alone, as the future of the current interglacial interval is unknown. We also note the absence of strong evidence of any Younger Dryas-like cooling event during the deglaciations preceding these previous interglacials. In its overall characteristics and compared with cold events, the Younger Dryas was a special event that was triggered by a catastrophic release of fresh water from Lake Agassiz to the northern
Atlantic (Teller et al. 2002). In the absence of a similar cold event punctuating termination $\mathrm{T} 2$ and termination $\mathrm{T} 4$, the Younger Dryas appears to be a one-time event that occurred as a consequence of glacially excavated topography combined with the position of the retreating ice front (Broecker 2003). One might intuitively suggest that the last deglaciation may have been interrupted during the Younger Dryas and resumed later delaying thus the transition to the warming peak of the Holocene. Our records show clearly that the transition into the warming peak MIS 9e was also delayed, yet the deglaciation may have been continuous.

As the early peak warming in the three intervals established, benthic $\delta^{18} \mathrm{O}$ in the three time-records show similarities in their mean values yet slightly lighter values are recorded at Site MD95-2040. At the depth of site MD95-2040, deep water mass might be modified by the entrainment of the warmer and more saline MOW (Voelker and de Abreu 2011).

The $\delta^{18} \mathrm{O}$ values within each interval at each site stabilized shortly after the establishment of the warming stages, we note constant light values within MIS 9e until the transition to the subsequent interstadial, MIS 9d. Planktic records show trends of increasing temperatures and salinities in the near-surface subpolar North Atlantic for the Holocene interval (Came et al. 2007), while the MIS 5e warming stage reached its increasing peak early in the interglacial stage and then stabilized (Mokeddem et al. 2014).

The comparisons among the three interglacials benthic $\delta^{13} \mathrm{C}$ ratios reveal that the lowest values are associated with MIS 9e at all sites (Fig. 4). It is worth noting that the preceding deglacial IRD event was one of the most prominent of the last half million years (McManus et al. 1999). This was also an interval containing a steep increase in northern summer insolation due to the amplification of precessional forcing by enhanced eccentricity (Berger and Loutre 1991; Tzedakis et al. 2009; Working group of PAGES 2016). One consequence of rapid melting and iceberg discharge would be the delivery of large quantities of meltwater to the subpolar region and potential reduction in deepwater formation (Ruddiman et al. 1980; Broecker and Denton 1989; McManus et al. 1999, 2004). During the last deglaciation, such a reduction has been inferred to propagate a sequence of events culminating in the outgassing of $\mathrm{CO}_{2}$ from the Southern Ocean, thus contributing to global deglaciation (Anderson et al. 2009; Denton et al. 2010; Clark et al. 2012). A greater freshwater input could have contributed to the previous deglaciation (Marino et al. 2015) and to the one preceding MIS 9 as well, based on the evidence presented here. Decreased buoyancy in the source region may have contributed to the persistent reduction and slow recovery observed in NADW early in the last interglacial MIS 5e (Oppo et al. 1997, 2006; McManus et al. 1999; Raymo et al. 2004; Galaassen et al. 2014; Mokeddem 
and McManus 2016) and even more so during MIS 9e. Although it is somewhat speculative, the large, extended perturbation in ocean circulation at the onset of MIS 9 may even have contributed to the single highest spike in atmospheric $\mathrm{CO}_{2}$ observed in Antarctic ice (Lüthi et al. 2008).

During the transition to MIS $9 \mathrm{~d}$, the benthic $\delta^{13} \mathrm{C}$ at all sites display similar values near $\sim 1 \%$ as those recorded during the Holocene and MIS 5e, generally believed to be intervals with high AMOC activity. This suggests at face value that AMOC was eventually more active during MIS 9d than during MIS 9e. In its glacial mode, the UNADW is typically highly ventilated compared with LNADW (Oppo and Lehman 1993; Sarnthein et al. 2001; Curry and Oppo 2005). As it appears that the poorly ventilated intermediate to deep water layers persisted beyond T4 through MIS $9 \mathrm{e}$, the best ventilated water depth could be expected to be the one in which Sites 982 and 984 are bathed, waters subject to UNADW. Site MD95-2040 should belong to the same group of ventilated depth sites as bathed in the depth of MOW which is ventilated similarly as UNADW (Sarnthein et al. 2001). Yet the data suggest that newly formed dense waters took deeper pathway to reach abyssal depths without passing by Site 984 . As the site is at mid-depth on the eastern flank of Reykjanes Ridge, this could be accomplished if the eastern part of intermediate water production in the Norwegian Sea that feed the ISOW was modified due to density changes in the GIN Seas (Thornalley et al. 2013; Kanzow and Zenk 2014; Langehaug et al. 2016). Thus, the western part water production in the Greenland Sea that overflow the Denmark Strait was the main contributor of the NADW (LNADW), as LSW (UNADW) may have also experienced reduction due to density variations.

\section{Conclusions}

The late-glacial interval of MIS 10 was characterized by extreme cold conditions in the North Atlantic region, with the polar front well to the south of Site 984 in the open Atlantic Ocean. During the T4 deglaciation, continued cold sea-surface temperatures were accompanied by freshening, first in the shallowest surface waters occupied by T. quinqueloba, and eventually at all near-surface depths occupied by the planktic foraminifera examined in this study. At this time a dramatic Heinrich-event type iceberg discharge, similar to the one observed farther south (McManus et al. 1999; Venz et al. 1999; Hodell and Curtis 2008; Voelker et al. 2010), also influenced Site 984, accounting for the cold, fresh, deglacial conditions. Subsequently, the polar front retreated north of the site, followed by the Arctic front, as peak interglacial conditions were established south of Iceland. Mild conditions prevailed from $\sim 335 \mathrm{ka}$ until $\sim 327$ ka during most of MIS 9e, with a return to polar conditions and renewed iceberg discharge in MIS 9d. In between the peak interglacial interval and ensuing stadial, a readvance of the Arctic front at about $326 \mathrm{ka}$ is evident in the dominant abundance of T. quinqueloba, as occurred during the last interglacial, MIS 5e (Mokeddem et al. 2014). The late interglacial dominance of T. quinqueloba at this site, south of Iceland, may be a harbinger of glacial inception in the region.

The sparse benthic $\delta^{13} \mathrm{C}$ at Site 984 during T4 nevertheless appears to be consistent with a regional pattern of reduced ventilation of deep and intermediate waters. In contrast to subsequent peak interglacial intervals, $\delta^{13} \mathrm{C}$ remained low well into MIS 9e interval, increasing only modestly until $\sim 325 \mathrm{ka}$. Although dense deep-waters similar to NADW may have formed in the North Atlantic during MIS 9e, they did not occupy or spread past the mid-depth location of Site 984 along the Reykjanes Ridge. Ventilation via DSOW may have been more important contributor to NADW during MIS 9e than the ISOW that bathes the study site today. High $\delta^{13} \mathrm{C}$ values characterizing nutrient-depleted northern-sourced waters became predominant during MIS 9d at this depth, although the limited regional data do not allow us to distinguish whether these were true intermediate waters or also influenced the deep North Atlantic.

Open Access This article is distributed under the terms of the Creative Commons Attribution 4.0 International License (http:// creativecommons.org/licenses/by/4.0/), which permits unrestricted use, distribution, and reproduction in any medium, provided you give appropriate credit to the original author(s) and the source, provide a link to the Creative Commons license, and indicate if changes were made.

\section{References}

Alley RB (1999) Making sense of millennial-scale climate change. Mech Global Clim Change Millenn Time Scales 112:385-494

Anderson RF, Ali S, Bradtmiller LI, Nielsen SHH, Fleisher MQ, Anderson BE, Burckle LH (2009) Wind-driven upwelling in the southern ocean and the deglacial rise in atmospheric $\mathrm{CO}_{2}$. Science 323:1443-1448

Barker S, Chen J, Gong X, Jonkers L, Knorr G, Thornalley D (2015) Icebergs not the trigger for North Atlantic cold events. Nature 520:333-336. doi:10.1038/nature14330. http://www. nature.com/nature/journal/v520/n7547/abs/nature14330. html\#supplementary-information

Bauch D, Carstens J, Wefer G (1997) Oxygen isotope composition of living Neogloboquadrina pachyderma (sin.) in the Arctic Ocean. Earth Planet Sci Lett 146:47-58. doi:10.1016/ s0012-821x(96)00211-7

Bé AWH (1960) Ecology of recent planktonic foraminifera: Part 2: bathymetric and seasonal distributions in the Sargasso Sea off Bermuda. Micropaleontology 6:373-392

Bé AWH, Tolderlund DS (1971) Distribution and ecology of living planktonic foraminifera in surface waters of the Atlantic and Indian Oceans. In: Funnel BM, Riedel WR (eds) The 
micropaleontology of oceans. Cambridge University Press, Cambridge, pp 105-149

Bemis BE, Spero HJ, Bijma J, Lea DW (1998) Reevaluation of the oxygen isotopic composition of planktonic foraminifera: Experimental results and revised paleotemperature equations. Paleoceanography 13:150-160. doi:10.1029/98pa00070

Berger A, Loutre MF (1991) Insolation values for the climate of the last 10 million years. Quatern Sci Rev 10:297-317. doi:10.1016/0277-3791(91)90033-Q

Berger A, Loutre MF (2010) Modeling the 100-kyr glacial-interglacial cycles. Global Planet Change 72:275-281. doi:10.1016/j. gloplacha.2010.01.003

Bond G (2001) Persistent solar influence on north Atlantic climate during the Holocene. Science 294:2130-2136

Bond $\mathrm{G}$ et al (1997) A Pervasive millennial-scale cycle in north Atlantic holocene and glacial climates. Science 278:12571266. doi:10.1126/science.278.5341.1257

Boyle EA, Keigwin LD (1982) Deep Circulation of the North Atlantic over the Last 200,000 Years: geochemical evidence. Science 218:784-787. doi:10.1126/science.218.4574.784

Boyle EA, Keigwin L (1987) North Atlantic thermohaline circulation during the past 20,000 years linked to high-latitude surface temperature. Nature 330:35-40

Broecker WS (2003) Does the trigger for abrupt climate change reside in the ocean or in the atmosphere? Science 300:15191522. doi: $10.1126 /$ science. 1083797

Broecker WS, Denton GH (1989) The role of ocean-atmosphere reorganizations in glacial cycles. Geochim Cosmochim Acta 53:2465-2501

Broecker WS, van Donk J (1970) Insolation changes, ice volumes and the $\mathrm{O}_{18}$ record in deep-sea cores. Rev Geophys Space Phys 8:169-198

Broecker WS, Bond GC, Klas M, Clark E, McManus JF (1992) Origin of the northern Atlantic's Heinrich events. Climate Dynamics 6:265-273

Came RE, Oppo DW, McManus JF (2007) Amplitude and timing of temperature and salinity variability in the subpolar North Atlantic over the past $10 \mathrm{ky}$. Geology 35:315-318

Chapman MR (2010) Seasonal production patterns of planktonic foraminifera in the NE Atlantic Ocean: Implications for paleotemperature and hydrographic reconstructions Paleoceanography 25:n/a-n/a. doi:10.1029/2008pa001708

Chapman MR, Shackleton NJ (1999) Global ice-volume fluctuations, North Atlantic ice-rafting events, and deep-ocean circulation changes between 130 and $70 \mathrm{ka}$. Geology 27:795-798. doi:10.1130/0091-7613(1999)027<0795:givfna > 2.3.co;2

Chapman MR, Shackleton NJ, Duplessy J-C (2000) Sea surface temperature variability during the last glacial-interglacial cycle: assessing the magnitude and pattern of climate change in the North Atlantic. Palaeogeogr Palaeoclimatol Palaeoecol 157:1-25. doi:10.1016/S0031-0182(99)00168-6

Clark PU et al (2012) Global climate evolution during the last deglaciation. Proc Natl Acad Sci 109:E1134-E1142. doi:10.1073/pnas.1116619109

Cortijo E, Lehman S, Keigwin L, Chapman M, Paillard D, Labeyrie L (1999) Changes in meridional temperature and salinity gradients in the north Atlantic ocean $\left(30^{\circ}-72^{\circ} \mathrm{N}\right)$ during the Last interglacial period. Paleoceanography 14:23-33. doi:10.1029 /1998pa900004

Curry WB, Oppo DW (2005) Glacial water mass geometry and the distribution of $\delta^{13} \mathrm{C}$ of $\Sigma \mathrm{CO}_{2}$ in the western Atlantic Ocean. Paleoceanography 20:PA1017. doi:10.1029/2004pa001021

Curry WB, Duplessy JC, Labeyrie LD, Shackleton NJ (1988) Changes in the distribution of $\delta^{13} \mathrm{C}$ of deep water $\Sigma \mathrm{CO}_{2}$ between the last glaciation and the Holocene. Paleoceanography $3: 317-341$
Curry RG, McCartney MS, Joyce TM (1998) Oceanic transport of subpolar climate signals to mid-depth subtropical waters. Nature 391:575-577

Curry WB, Marchitto TM, McManus JF, Oppo DW, Laarkamp KL (1999) Millennial-scale changes in ventilation of the thermocline, intermediate, and deep waters of the glacial north Atlantic. In: Mechanisms of global climate change at millennial time scales. American Geophysical Union, New Jersey, pp 59-76. doi:10.1029/GM112p0059

Denton GH, Karlén W (1973) Holocene climatic variationstheir pattern and possible cause. Quatern Res 3:155-174. doi:10.1016/0033-5894(73)90040-9

Denton GH, Anderson RF, Toggweiler JR, Edwards RL, Schaefer JM, Putnam AE (2010) The last glacial termination. Science 328:1652-1656. doi:10.1126/science.1184119

DePaolo DJ, Maher K, Christensen JN, McManus J (2006) Sediment transport time measured with U-series isotopes: results from ODP North Atlantic drift site 984. Earth Planet Sci Lett 248:394-410. doi:10.1016/j.eps1.2006.06.004

Desprat S, Goni MFS, McManus JF, Duprat J, Cortijo E (2009) Millennial-scale climatic variability between 340000 and 270000 years ago in SW Europe: evidence from a NW Iberian margin pollen sequence Climate Past 5:53-72

Dickson RR, Brown J (1994) The production of North Atlantic Deep Water: Sources, rates, and pathways. J Geophys Res Oceans 99:12319-12341. doi:10.1029/94jc00530

Duplessy J-C, Shackleton NJ, Matthews RK, Prell W, Ruddiman WF, Caralp M, Hendy $\mathrm{CH}(1984){ }^{13} \mathrm{C}$ record of benthic foraminifera in the last interglacial ocean: implications for the carbon cycle and the global deep water circulation. Quatern Res 21:225-243. doi:10.1016/0033-5894(84)90099-1

Duplessy JC, Shackleton NJ, Fairbanks RG, Labeyrie L, Oppo D, Kallel N (1988) Deepwater source variations during the last climatic cycle and their impact on the global deepwater circulation. Paleoceanography 3:343-360. doi:10.1029/ PA003i003p00343

Duplessy JC, Labeyrie L, Juilletleclerc A, Maitre F, Duprat J, Sarnthein M (1991) Surface salinity reconstruction of the northatlantic ocean during the last glacial maximum. Oceanol Acta $14: 311-324$

Fairbanks RG, Sverdlove M, Free R, Wiebe PH, Be AWH (1982) Vertical distribution and isotopic fractionation of living planktonic foraminifera from the Panama Basin. Nature 298:841-844

Fedorov KN (1986) He physical nature and structure of oceanic fronts. coastal and estuarine studies, vol 19, 1 edn. SpringerVerlag New York

Field DB (2004) Variability in vertical distributions of planktonic foraminifera in the California current: relationships to vertical ocean structure. Paleoceanography 19:PA2014. doi:10.1029/20 03pa000970

Flower BP, Oppo DW, McManus JF, Venz KA, Hodell DA, Cullen JL (2000) North Atlantic intermediate to deep water circulation and chemical stratification during the past 1 Myr. Paleoceanography 15:388-403. doi:10.1029/1999pa000430

Fronval T, Jansen E, Haflidason H, Sejrup HP (1998) Variability in surface and deep water conditions in the nordic seas during the last interglacial period. Quatern Sci Rev 17:963-985 doi:10.1016/s0277-3791(98)00038-9

Galaasen EV, Ninnemann US, Irvalı N, Kleiven HF, Rosenthal Y, Kissel C, Hodell DA (2014) Rapid reductions in North Atlantic deep water during the peak of the last interglacial period. Science. doi: $10.1126 /$ science. 1248667

Ganssen GM, Kroon D (2000) The isotopic signature of planktonic foraminifera from NE Atlantic surface sediments: implications for the reconstruction of past oceanic conditions. J Geol Soc Lond 157:693-699 
Gebbie G (2014) How much did glacial North Atlantic water shoal? Paleoceanography 29:190-209. doi:10.1002/2013pa002557

Ginzburg A, Kostianoy A (2002) Fronts and mixing processes oceanography, encyclopedia of life support systems (EOLSS), UNESCO/EOLSS Publishers, Oxford. http://www.eolss.net

Grossman EL (1987) Stable isotopes in modern benthic foraminifera; a study of vital effect. J Foramin Res 17:48-61. doi:10.2113/gsjfr.17.1.48

Hall IR, McCave IN, Chapman MR, Shackleton NJ (1998) Coherent deep flow variation in the Iceland and American basins during the last interglacial. Earth Planet Sci Lett 164:15-21. doi:10.1016/s0012-821x(98)00209-x

Hays JD, Imbrie J, Shackleton NJ (1976) Variations in the Earth's orbit: pacemaker of the ice ages. Science 194:1121-1132. doi:10.1126/science.194.4270.1121

Heinrich H (1988) Origin and consequences of cyclic ice rafting in the northeast Atlantic ocean during the past 130,000 years. Quatern Res 29:142-152. doi:10.1016/0033-5894(88)90057-9

Helmke JP, Bauch HA (2003) Comparison of glacial and interglacial conditions between the polar and subpolar North Atlantic region over the last five climatic cycles. Paleoceanography 18:1036. doi:10.1029/2002pa000794

Hemming SR (2004) Heinrich events: massive late pleistocene detritus layers of the north Atlantic and their global climate imprint. Rev Geophys 42:RG1005. doi:10.1029/200 $3 \mathrm{rg} 000128$

Henry LG, McManus JF, Curry WB, Roberts NL, Piotrowski AM, Keigwin LD (2016) North Atlantic ocean circulation and abrupt climate change during the last glaciation. Science 353:470-474. doi:10.1126/science.aaf5529

Herold N, Yin QZ, Karami MP, Berger A (2012) Modelling the climatic diversity of the warm interglacials. Quatern Sci Rev 56:126-141. doi:10.1016/j.quascirev.2012.08.020

Heusser LE, Heusser C, McManus JF, Mix AC (2006) Chilean and southeast Pacific paleoclimate variations during the last glacial cycle: directly correlated pollen and d180 from ODP Site 1234 . Quatern Sci Rev 25:3404-3415

Hillaire-Marcel C, de Vernal A, Bilodeau G, Weaver AJ (2001) Absence of deep-water formation in the Labrador Sea during the last interglacial period. Nature 410:1073-1077

Hodell DA, Curtis JH (2008) Oxygen and carbon isotopes of detrital carbonate in North Atlantic Heinrich Events. Mar Geol 256:3035. doi:10.1016/j.margeo.2008.09.010

Hodell DA, Charles CD, Ninnemann US (2000) Comparison of interglacial stages in the south Atlantic sector of the Southern Ocean for the past 450 kyrs: implications for marine isotope stage (MIS) 11. Global Planet Change 24:7-26

Hodell DA, Minth EK, Curtis JH, McCave IN, Hall IR, Channell JET, Xuan C (2009) Surface and deep-water hydrography on Gardar Drift (Iceland Basin) during the last interglacial period. Earth Planet Sci Lett 288:10-19. doi:10.1016/j.epsl.2009.08.040

Imbrie J, Kipp NG (1971) A new micropaleontological method for paleoclimatology: application to a late pleistocene caribbean core. In: Turekian KK (ed) The late cenozoic glacial ages. Yale University Press, New Haven, pp 71-91

Imbrie J et al (1984) The orbital theory of pleistocene climate : support from a revised chronology of the marine delta18 $\mathrm{O}$ record. In: Berger A, Imbrie J, Hays H, Kukla G, Saltzman B (eds) Milankovitch and climate: understanding the response to astronomical forcing. D. Reidel, Norwell, p 269

Imbrie $\mathbf{J}$ et al (1992) On the structure and origin of major glaciation cycles 1. Linear Responses Milankovitch Forcing Paleoceanogr 7:701-738. doi:10.1029/92pa02253

Irvalı $\mathrm{N}$ et al (2012) Rapid switches in subpolar North Atlantic hydrography and climate during the Last Interglacial (MIS 5e). Paleoceanography 27:PA2207. doi:10.1029/2011pa002244
Johannessen T, Jansen E, Flatøy A, Ravelo AC (1994) The relationship between surface water masses. oceanographic fronts and paleoclimatic proxies in surface sediments of Greenland, Iceland, Norwegian Seas NATO ASI Ser 1 17:61-85

Jonkers L, Brummer G-JA, Peeters FJC, van Aken HM, De Jong MF (2010) Seasonal stratification, shell flux, and oxygen isotope dynamics of left-coiling $N$. pachyderma and $T$. quinqueloba in the western subpolar North Atlantic. Paleoceanography 25:PA2204. doi:10.1029/2009pa001849

Jonkers L, van Heuven S, Zahn R, Peeters FJC (2013) Seasonal patterns of shell flux, $\delta^{18} \mathrm{O}$ and $\delta^{13} \mathrm{C}$ of small and large $N$. pachyderma (s) and G. bulloides in the subpolar North Atlantic. Paleoceanography 28:164-174. doi:10.1002/palo.20018

Jouzel J et al (2007) Orbital and millennial antarctic climate variability over the past 800,000 Years. Science 317:793-796. doi:10.1126/science. 1141038

Kandiano ES, Bauch HA (2003) Surface ocean temperatures in the north-east Atlantic during the last 500000 years: evidence from foraminiferal census data. Terra Nova 15:265-271. doi:10.1046/j.1365-3121.2003.00488.x

Kandiano ES, Bauch HA, Müller A (2004) Sea surface temperature variability in the North Atlantic during the last two glacialinterglacial cycles: comparison of faunal, oxygen isotopic, and $\mathrm{Mg} / \mathrm{Ca}$-derived records. Palaeogeogr Palaeoclimatol Palaeoecol 204:145-164. doi:10.1016/s0031-0182(03)00728-4

Kanzow T, Zenk W (2014) Structure and transport of the Iceland Scotland overflow plume along the Reykjanes ridge in the Iceland basin deep sea research part I: oceanographic. Res Pap Hist Med Assoc 86:82-93. doi:10.1016/j.dsr.2013.11.003

King AL, Howard WR (2000) Middle pleistocene sea-surface temperature change in the southwest Pacific ocean on orbital and suborbital timescales. Geology 28:659-662

Koç N, Labeyrie L, Manthé S, Flower BP, Hodell DA, Aksu A (2001) The last occurrence of Proboscia curvirostris in the North Atlantic marine isotope stages 9-8. Mar Micropaleontol 41:923. doi:10.1016/s0377-8398(00)00054-2

Kohfeld KE, Fairbanks RG, Smith SL, Walsh ID (1996) Neogloboquadrina pachyderma (sinistral coiling) as paleoceanographic tracers in polar oceans: Evidence from northeast water polynya plankton tows, sediment traps, and surface sediments. Paleoceanography 11:679-699. doi:10.1029/96pa02617

Kostygov S, Kandiano E, Bauch H (2010) Reconstruction of deepwater conditions in the North Atlantic during MIS 9 based on benthic foraminiferal assemblages. Oceanology 50:397-407. doi:10.1134/s0001437010030094

Kroopnick PM (1985) The distribution of ${ }^{13} \mathrm{C}$ of $\Sigma \mathrm{CO}_{2}$ in the world oceans Deep sea research part A oceanographic. Res Pap Hist Med Assoc 32:57-84. doi:10.1016/0198-0149(85)90017-2

Kučera M (2007) Planktonic foraminifera as tracers of past oceanic environments. In: Hillaire-Marcel C, de Vernal A (eds) Proxies in late cenozoic paleocenaography, vol developments in marine geology. Elsevier, Amsterdam, pp 213-262

Lang N, Wolff EW (2010) Interglacial and glacial variability from the last $800 \mathrm{ka}$ in marine, ice and terrestrial archives. Clim Past Discuss 6:2223-2266. doi:10.5194/cpd-6-2223-2010, 2010.

Langehaug HR, Mjell TL, Otterå $\mathrm{OH}$, Eldevik T, Ninnemann US, Kleiven HF (2016) On the reconstruction of ocean circulation and climate based on the "Gardar Drift". Paleoceanography 31:399-415. doi:10.1002/2015pa002920

Lisiecki LE, Raymo ME (2005) A Pliocene-Pleistocene stack of 57 globally distributed benthic $\delta^{18} \mathrm{O}$ records. Paleoceanography 20:PA1003. doi:10.1029/2004pa001071

Luthi D et al (2008) High-resolution carbon dioxide concentration record 650,000-800,000 years before present. Nature 453:379$382 . \quad$ http://www.nature.com/nature/journal/v453/n7193/ suppinfo/nature06949_S1.html 
Lynch-Stieglitz J, Curry WB, Slowey N (1999) A geostrophic transport estimate for the Florida Current from the oxygen isotope composition of benthic foraminifera. Paleoceanography 14:360-373. doi:10.1029/1999pa900001

Lynch-Stieglitz J et al (2007) Atlantic meridional overturning circulation during the last glacial maximum. Science 316:66-69

Marchitto TM, Broecker WS (2006) Deep water mass geometry in the glacial Atlantic ocean: a review of constraints from the paleonutrient proxy $\mathrm{Cd} / \mathrm{Ca}$. Geochem Geophys Geosyst 7:n/a-n/a. doi:1 $0.1029 / 2006 \mathrm{gc} 001323$

Marino G et al. (2015) Bipolar seesaw control on last interglacial sea level. Nature 522:197-201 doi:10.1038/nature14499. http:// www.nature.com/nature/journal/v522/n7555/abs/nature14499. html\#supplementary-information

Mayewski PA et al (2004) Holocene climate variability. Quatern Res 62:243-255. doi:10.1016/j.yqres.2004.07.001

McCartney MS (1992) Recirculating components of the deep boundary current of the northern North Atlantic. Prog Oceanogr 29:283-383

McCartney MS, Talley LD (1984) Warm-to-cold water conversion in the northern north Atlantic ocean. J Phys Oceanogr 14:922935. doi:10.1175/1520-0485(1984)014<0922:WTCWCI >2.0 $\mathrm{CO} ; 2$

McManus JF, Bond GC, Broecker WS, Johnsen S, Labeyrie L, Higgins S (1994) High-resolution climate records from the North Atlantic during the last interglacial. Nature 371:326-329

McManus JF, Major CO, Flower B, Fronval T (1996) Variability in sea-surface conditions in the north Atlantic-Arctic gateways during the last 140,000 years. In Thiede J, Myhre AM, Firth JV, Johnson GL, Ruddiman WF eds Proceedings of the ocean drilling program scientific results 151. Ocean Drilling Program, College Station, pp 437-443

McManus JF, Anderson RF, Broecker WS, Fleisher MQ, Higgins SM (1998) Radiometrically determined sedimentary fluxes in the sub-polar North Atlantic during the last 140,000 years. Earth Planet Sci Lett 155:29-43. doi:10.1016/s0012-821(97)00201-x

McManus JF, Oppo DW, Cullen JL (1999) A 0.5-million-year record of millennial-scale climate variability in the north Atlantic. Science 283:971-975. doi:10.1126/science.283.5404.971

McManus JF, Oppo DW, Keigwin LD, Cullen JL, Bond GC (2002) Thermohaline circulation and prolonged interglacial warmth in the north Atlantic. Quatern Res 58:17-21. doi:10.1006/ qres.2002.2367

McManus JF, Oppo DW, Cullen JL, Healey SL (2003) Marine Isotope Stage 11 (MIS 11): Analog for Holocene and future climate? In: Droxler A, Poore R, Burckle L, Osterman L, eds. Geophysical monograph 137: Earth's climate and orbital eccentricity: the marine isotope stage 11 question AGU vol 137, pp 69-85

McManus JF, Francois R, Gherardi JM, Keigwin LD, Brown-Leger $S$ (2004) Collapse and rapid resumption of Atlantic meridional circulation linked to deglacial climate changes. Nature 428:834-837. http://www.nature.com/nature/journal/v428/ n6985/suppinfo/nature02494_S1.html

Mokeddem Z, McManus JF (2016) Persistent climatic and oceanographic oscillations in the subpolar North Atlantic during the MIS 6 glaciation and MIS 5 interglacial Paleoceanography. doi: $10.1002 / 2015 \mathrm{pa002813}$

Mokeddem Z, McManus JF, Oppo DW (2014) Oceanographic dynamics and the end of the last interglacial in the subpolar North Atlantic. Proc Natl Acad Sci 111:11263-11268. doi:10.1073/pnas.1322103111

Mollenhauer G, McManus JF, Wagner T, McCave IN, Eglinton TI (2011) Radiocarbon and 230Th data reveal rapid redistribution and temporal changes in sediment focussing at a North Atlantic drift. Earth Planet Sci Lett 301:373-381 doi:10.1016/j. epsl.2010.11.022
Mulitza S, Dürkoop A, Hale W, Wefer G, Stefan Niebler H (1997) Planktonic foraminifera as recorders of past surface-water stratification. Geology 25:335-338. doi:10.1130/0091-7613(1997)025<0335:pfarop > 2.3.co;2

Naafs BDA, Hefter J, Stein R (2013) Millennial-scale ice rafting events and Hudson Strait Heinrich (-like) events during the late pliocene and pleistocene: a review. Quatern Sci Rev 80:1-28

O'Brien SR, Mayewski PA, Meeker LD, Meese DA, Twickler MS, Whitlow SI (1995) Complexity of holocene climate as reconstructed from a Greenland Ice Core. Science 270:1962-1964. doi:10.1126/science.270.5244.1962

Oppo DW, Fairbanks RG (1987) Variability in the deep and intermediate water circulation of the Atlantic Ocean during the past 25,000 years: northern Hemisphere modulation of the southern Ocean. Earth Planet Sci Lett 86:1-15. doi:10.1016/0012-821X(87)90183-X

Oppo DW, Fairbanks RG (1990) Atlantic Ocean thermohaline circulation of the last 150,000 years: relationship to climate and atmospheric $\mathrm{CO}_{2}$. Paleoceanography 5:277-288

Oppo DW, Horowitz M (2000) Glacial deep water geometry: south Atlantic benthic foraminiferal $\mathrm{Cd} / \mathrm{Ca}$ and $\delta^{13} \mathrm{C}$ evidence. Paleoceanography 15:147-160. doi:10.1029/1999pa000436

Oppo DW, Lehman SJ (1993) Mid-depth circulation of the subpolar north Atlantic during the last glacial maximum. Science 259:1148-1152. doi:10.1126/science.259.5098.1148

Oppo DW, Lehman SJ (1995) Suborbital timescale variability of north Atlantic deep water during the past 200,000 years. Paleoceanography 10:901-910. doi:10.1029/95pa02089

Oppo DW, Horowitz M, Lehman SJ (1997) marine core evidence for reduced deep water production during termination II followed by a relatively stable substage $5 \mathrm{e}$ (Eemian). Paleoceanography 12:51-63. doi:10.1029/96pa03133

Oppo DW, Keigwin LD, McManus JF, Cullen JL (2001) Persistent suborbital climate variability in marine isotope stage 5 and termination II. Paleoceanography 16:280-292. doi:10.1029/200 Opa000527

Oppo DW, McManus JF, Cullen JL (2006) Evolution and demise of the Last Interglacial warmth in the subpolar North Atlantic. Quatern Sci Rev 25:3268-3277. doi:10.1016/j. quascirev.2006.07.006

Oppo DW, Curry WB, McManus JF (2015) What do benthic $\delta^{13} \mathrm{C}$ and $\delta^{18} \mathrm{O}$ data tell us about Atlantic circulation during Heinrich Stadial 1? Paleoceanography 30:353-368. doi:10.1002/20 $14 \mathrm{pa} 002667$

Ostermann DR, Curry WB, Oafsson J, Honjo S (1998) Variability of foraminiferal flux and isotopic composition at sites around Iceland and the Sea of Okhotsk, with a special focus on $N$. pachyderma (sinistral and dextral), and G. quinqueloba. In: Proceedings Sixth International Conference on Paleoceanography, Lisbon, Portugal, p 180

Ostermann DR, Olafsson J, Manganini S, Curry WB, Honjo S (2001) A dramatic increase in particle flux in the Iceland Sea since 1997, results from a 15-year time series. Hokkaido University, Japan

Past Interglacials Working Group of PAGES (2016) Interglacials of the last 800,000 years. Rev Geophys 54:162-219. doi:10.1002 $12015 \mathrm{rg} 000482$

Petit JR et al (1999) Climate and atmospheric history of the past 420,000 years from the Vostok ice core, Antarctica. Nature 399:429-436. http://www.nature.com/nature/journal/v399/ n6735/suppinfo/399429a0_S1.html

Pflaumann U et al (2003) Glacial north Atlantic: sea-surface conditions reconstructed by GLAMAP 2000. Paleoceanography 18:1065. doi:10.1029/2002pa000774

Praetorius SK, McManus JF, Oppo DW, Curry WB (2008) Episodic reductions in bottom-water currents since the last ice age. 
Nature Geosci 1:449-452. http://www.nature.com/ngeo/journal/ v1/n7/suppinfo/ngeo227_S1.html

Raymo ME, Ruddiman WF, Shackleton NJ, Oppo DW (1990) Evolution of Atlantic-Pacific ${ }^{313} \mathrm{C}$ gradients over the last 2.5 m.y. Earth Planet Sci Lett 97:353-368

Raymo ME, Oppo DW, Curry W (1997) The mid-pleistocene climate transition: a deep sea carbon isotopic perspective. Paleoceanography 12:546-559. doi:10.1029/97pa01019

Raymo ME et al (2004) Stability of north Atlantic water masses in face of pronounced climate variability during the Pleistocene. Paleoceanography 19:PA2008. doi:10.1029/2003pa000921

Raymo ME, Lisiecki LE, Nisancioglu KH (2006) Plio-pleistocene ice volume, antarctic climate, and the global $\delta^{18} \mathrm{O}$ record. Science 313:492-495. doi:10.1126/science.1123296

Read JF (2000) CONVEX-91: water masses and circulation of the Northeast Atlantic subpolar gyre Progress. In Oceanography 48:461-510. doi:10.1016/s0079-6611(01)00011-8

Rickaby REM, Elderfield H (2005) Evidence from the high-latitude North Atlantic for variations in Antarctic Intermediate water flow during the last deglaciation Geochem Geophys Geosyst 6:Q05001. doi:10.1029/2004gc000858

Rodrigues T, Voelker AHL, Grimalt JO, Abrantes F, Naughton F (2011) Iberian Margin sea surface temperature during MIS 15 to $9(580-300 \mathrm{ka})$ : glacial suborbital variability versus interglacial stability. Paleoceanography 26:PA1204. doi:10.1029/201 0pa001927

Roucoux KH, Tzedakis PC, de Abreu L, Shackleton NJ (2006) Climate and vegetation changes 180,000 to 345,000 years ago recorded in a deep-sea core off Portugal. Earth Planet Sci Lett 249:307-325. doi:10.1016/j.eps1.2006.07.005

Ruddiman WF (1977) Late Quaternary deposition of ice-rafted sand in the subpolar North Atlantic (lat 40\{degrees\} to 65\{degrees\}N). Geol Soc Am Bull 88:1813-1827. doi:10.1130/0016-7606(1977)88<1813:lqdois >2.0.co;2

Ruddiman WF (2007) The early anthropogenic hypothesis: Challenges and responses. Rev Geophys 45:RG4001. doi:10.1029/2 $006 \mathrm{rg} 000207$

Ruddiman WF, McIntyre A (1973) Time-transgressive deglacial retreat of polar waters from the North Atlantic. Quatern Res 3:117-130. doi:10.1016/0033-5894(73)90058-6

Ruddiman WF, Molfino B, Esmay A, Pokras E (1980) Evidence bearing on the mechanism of rapid deglaciation. Climate Change 3:65-87

Rudels B, Fahrbach E, Meincke J, Budéus G, Eriksson P (2002) The east Greenland current and its contribution to the Denmark Strait overflow ICES. J Marine Science J Conseil 59:11331154. doi: $10.1006 /$ jmsc. 2002.1284

Sarnthein M et al. (2001) Fundamental modes and abrupt changes in north atlantic circulation and climate over the last $60 \mathrm{ky}-$ concepts, reconstruction and numerical modeling. In: Schäfer P, Ritzrau W, Schlüter M, Thiede J (eds) The northern north Atlantic: a changing environment. Springer Berlin Heidelberg, Berlin, Heidelberg, pp 365-410. doi:10.1007/978-3-642-56876-3_21

Sautter LR, Thunell RC (1989) Seasonal succession of planktonic foraminifera; results from a four-year time-series sediment trap experiment in the Northeast Pacific The. J Foramin Res 19:253267. doi:10.2113/gsjfr.19.4.253

Schmitz WJ, McCartney MS (1993) On the north Atlantic circulation. Rev Geophys 31:29-49. doi:10.1029/92rg02583

Schrag DP, Adkins JF, McIntyre K, Alexander J, Hodell DA, Charles CD, McManus JF (2002) The oxygen isotopic composition of seawater during the last Glacial maximum. Quatern Sci Rev 21:331-342

Shackleton NJ (1987) oxygen isotopes, ice volume and sea level. Quatern Sci Rev 6:183-190
Shackleton NJ, Hall MA, Vincent E (2000) Phase relationships between millennial-scale events 64,000-24,000 years ago. Paleoceanography 15:565-569. doi:10.1029/2000pa000513

Shackleton NJ, Chapman M, Sánchez-Goñi MF, Pailler D, Lancelot Y (2002) The classic marine isotope substage 5e. Quatern Res 58:14-16. doi:10.1006/qres.2001.2312

Simstich J, Sarnthein M, Erlenkeuser H (2003) Paired [delta]18O signals of Neogloboquadrina pachyderma (s) and Turborotalita quinqueloba show thermal stratification structure in Nordic Seas. Mar Micropaleontol 48:107-125. doi:10.1016/ s0377-8398(02)00165-2

Stirling CH, Esat TM, Lambeck K, McCulloch MT, Blake SG, Lee D-C, Halliday AN (2001) Orbital forcing of the marine isotope stage 9 interglacial. Science 291:290-293

Teller JT, Leverington DW, Mann JD (2002) Freshwater outbursts to the oceans from glacial Lake Agassiz and their role in climate change during the last deglaciation. Quatern Sci Rev 21:879887. doi:10.1016/S0277-3791(01)00145-7

Thornalley DJR et al. (2013) Long-term variations in Iceland-Scotland overflow strength during the Holocene. Climate Past 9:2073-2084

Tzedakis PC et al (1997) Comparison of terrestrial and marine records of changing climate of the last 500,000 years. Earth Planet Sci Lett 150:171-176. doi:10.1016/s0012-821x(97)00078-2

Tzedakis PC, Roucoux KH, de Abreu L, Shackleton NJ (2004) The duration of forest stages in southern Europe and interglacial climate variability. Science 306:2231-2235. doi:10.1126/ science. 1102398

Tzedakis PC, Raynaud D, McManus JF, Berger A, Brovkin V, Kiefer T (2009) Interglacial diversity. Nature Geosci 2:751755. http://www.nature.com/ngeo/journal/v2/n11/suppinfo/ ngeo660_S1.html

Tzedakis PC, Wolff EW, Skinner LC, Brovkin V, Hodell DA, McManus JF, Raynaud D (2012) Can we predict the duration of an interglacial? Climate Past 8:1473-1485

Venz KA, Hodell DA, Stanton C, Wamke DA (1999) A $1.0 \mathrm{Myr}$ record of glacial north Atlantic intermediate water variability from ODP site 982 in the northeast Atlantic. Paleoceanography $14: 42-52$

Voelker AHL, de Abreu L (2011) A Review of Abrupt Climate Change Events in the Northeastern Atlantic Ocean (Iberian Margin): Latitudinal, Longitudinal, and Vertical Gradients. In: Abrupt Climate Change: Mechanisms, Patterns, and Impacts, vol 193. Geophysical Monograph Series AGU, Washington, DC, pp 15-37. doi:10.1029/2010gm001021

Voelker AHL et al. (2010) Variations in mid-latitude North Atlantic surface water properties during the mid-Brunhes (MIS 9-14) and their implications for the thermohaline circulation. Clim Past 6:531-552. doi:10.5194/cp-6-531-2010

Waelbroeck C et al (2002) Sea-level and deep water temperature changes derived from benthic foraminifera isotopic records. Quatern Sci Rev 21:295-305. doi:10.1016/ s0277-3791(01)00101-9

Weinelt $\mathrm{M}$ et al. (2001) Paleoceanographic proxies in the northern north Atlantic. In: Schäfer P, Ritzrau W, Schlüter M, Thiede J (eds) The northern North Atlantic: a changing environment. Springer Berlin Heidelberg, Berlin, Heidelberg, pp 319-352. doi:10.1007/978-3-642-56876-3_19

Worthington LV, Wright WR (eds) (1970) North Atlantic Ocean atlas: of potential temperature and salinity in the deep water including temperature, salinity and oxygen profiles from the Erika Dan cruise of 1962. vol 2, Woods Hole Oceanographic Institution, Mass

Wu G, Hillaire-Marcel C (1994) Oxygen isotope compositions of sinistral Neogloboquadrina pachyderma tests in surface sediments: 
North Atlantic Ocean. Geochim Cosmochim Acta 58:13031312. doi:10.1016/0016-7037(94)90383-2

Xie RC, Marcantonio F, Schmidt MW (2014) Reconstruction of intermediate water circulation in the tropical North Atlantic during the past 22,000 years. Geochim Cosmochim Acta 140:455-467. doi:10.1016/j.gca.2014.05.041

Yang Q, Dixon TH, Myers PG, Bonin J, Chambers D, van den Broeke MR (2016) Recent increases in Arctic freshwater flux affects
Labrador Sea convection and Atlantic overturning circulation Nat Commun 7. doi:10.1038/ncomms10525

Yin QZ, Berger A (2015) Interglacial analogues of the Holocene and its natural near future. Quatern Sci Rev 120:28-46. doi:10.1016/j.quascirev.2015.04.008 